Nevada

Environmental

Restoration

Project

\title{
Addendum to the Closure Report for Corrective Action Unit 358: \\ Areas 18, 19, 20 Cellars/Mud Pits \\ Nevada Test Site, Nevada
}

Controlled Copy No::

Revision No.: 0

October 2008

Approved for public release; further dissemination unlimited.

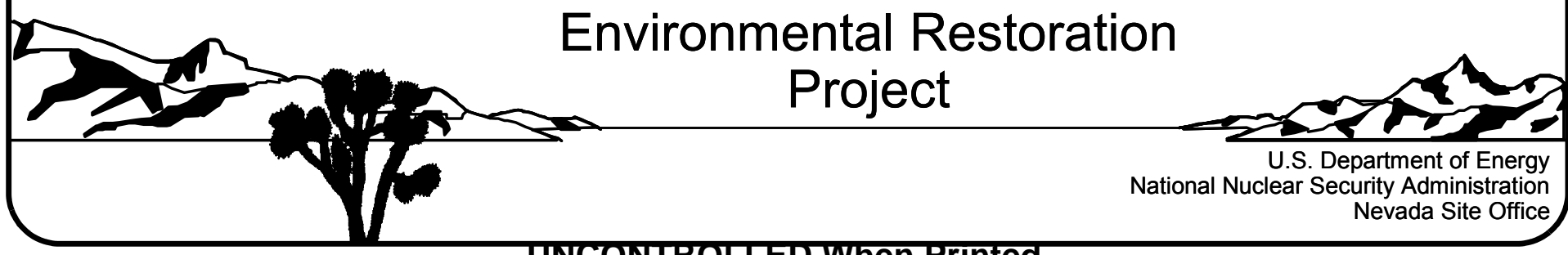


Available for public sale, in paper, from:

U.S. Department of Commerce

National Technical Information Service

5285 Port Royal Road

Springfield, VA 22161

Phone: 800.553 .6847

Fax: 703.605.6900

Email: orders@ntis.gov

Online ordering: http://www.ntis.gov/ordering.htm

Available electronically at $\underline{h t p: / / w w w . o s t i . g o v / b r i d g e ~}$

Available for a processing fee to U.S. Department of Energy and its contractors, in paper, from:

U.S. Department of Energy

Office of Scientific and Technical Information

P.O. Box 62

Oak Ridge, TN 37831-0062

Phone: 865.576 .8401

Fax: 865.576.5728

Email: reports@adonis.osti.gov

Reference herein to any specific commercial product, process, or service by trade name, trademark, manufacturer, or otherwise, does not necessarily constitute or imply its endorsement, recommendation, or favoring by the United States Government or any agency thereof or its contractors or subcontractors. 


\title{
ADDENDUM TO THE CLOSURE REPORT FOR CORRECTIVE ACTION UNIT 358: AREAS 18, 19, 20 CELLARS/MUD PITS NEVADA TEST SITE, NEVADA
}

\author{
U.S. Department of Energy \\ National Nuclear Security Administration \\ Nevada Site Office \\ Las Vegas, Nevada
}

Controlled Copy No.:

Revision No.: 0

October 2008

Approved for public release; further dissemination unlimited. 


\section{Addendum to the Closure Report for Removal of the Use Restriction}

This document constitutes an addendum to the January 2004, Closure Report for Corrective Action Unit 358: Areas 18, 19, 20 Cellars/Mud Pits as described in the document Recommendations and Justifications for Modifications for Use Restrictions Established under the U.S. Department of Energy, National Nuclear Security Administration Nevada Site Office Federal Facility Agreement and Consent Order (UR Modification document) dated February 2008. The UR Modification document was approved by NDEP on February 26, 2008. The approval of the UR Modification document constituted approval of each of the recommended UR modifications. In conformance with the UR Modification document, this addendum consists of:

- This cover page that refers the reader to the UR Modification document for additional information

- The cover and signature pages of the UR Modification document

- The NDEP approval letter

- The corresponding section of the UR Modification document

This addendum provides the documentation justifying the cancellation of the URs for:

- CAS 20-23-02, Postshot Cellar

- CAS 20-23-03, Cellar

- CAS 20-23-04, Postshot Cellar

- CAS 20-23-05, Postshot Cellar

- CAS 20-23-06, Cellar

- CAS 20-37-01, Cellar \& Mud Pit

- CAS 20-37-05, Cellar

These URs were established as part of Federal Facility Agreement and Consent Order (FFACO) corrective actions and were based on the presence of contaminants at concentrations greater than the action levels established at the time of the initial investigation (FFACO, 1996; as amended August 2006).

Since these URs were established, practices and procedures relating to the implementation of risk-based corrective actions (RBCA) have changed. Therefore, these URs were re-evaluated against the current RBCA criteria as defined in the Industrial Sites Project Establishment of Final Action Levels (NNSA/NSO, 2006c). This re-evaluation consisted of comparing the original data (used to define the need for the URs) to risk-based final action levels (FALs) developed using the current Industrial Sites RBCA process.

The re-evaluation resulted in a recommendation to remove these URs because contamination is not present at these sites above the risk-based FALs. Requirements for inspecting and maintaining these URs will be canceled, and the postings and signage at each site will be removed. Fencing and posting may be present at these sites that are 
unrelated to the FFACO URs such as for radiological control purposes as required by the NV/YMP Radiological Control Manual (NNSA/NSO, 2004f). This modification will not affect or modify any non-FFACO requirements for fencing, posting, or monitoring at these sites. 
Nevada

Environmental

Restoration

Project

Recommendations and Justifications for Modifications for Use Restrictions Established under the U.S. Department of Energy, National Nuclear Security Administration Nevada Site Office

Federal Facility Agreement and Consent Order

Controlled Copy No.:

Revision No.: 0

February 2008

Approved for public release; further dissemination unlimited.

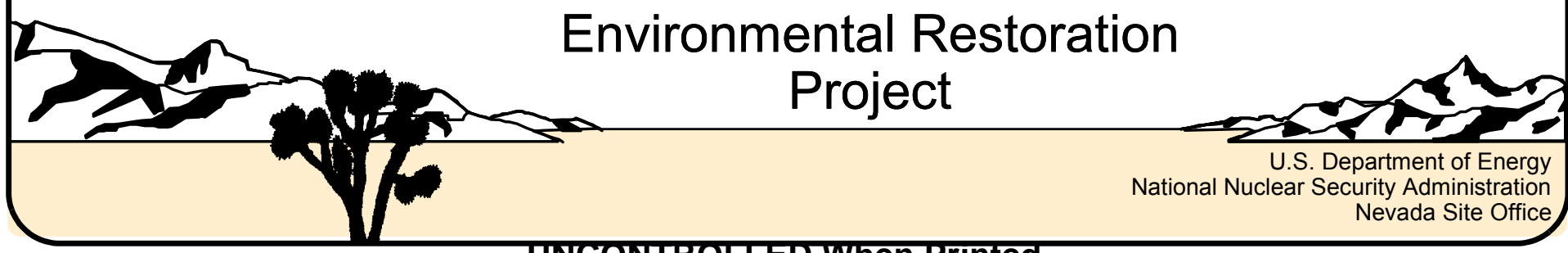


Recommendations and Justifications for Modifications for Use Restrictions Established under the U.S. Department of Energy, National Nuclear Security Administration Nevada Site Office Federal Facility Agreement and Consent Order

Approved by: /s/ Kevin J. Cabble

Date: $02 / 05 / 2008$

Kevin J. Cabble

Federal Sub-Project Director

Industrial Sites Sub-Project

Approved by:

/s/ John B. Jones

Date: $02 / 04 / 2008$

John B. Jones

Acting Federal Project Director

Environmental Restoration Project 
February 26, 2008

John B. Jones

Acting Federal Project Director

Environmental Restoration Project

National Nuclear Security Administration

Nevada Site Office

P. O. Box 98518

Las Vegas, NV 89193-8518

RE: Approval of Recommendations and Justifications for Modifications for Use Restrictions

Established under the U.S. Department of Energy, National Nuclear Security Administration, Nevada Site Office Federal Facility Agreement and Consent Order

Dear Mr. Jones:

The Nevada Division of Environmental Protection, Bureau of Federal Facilities (NDEP) staff has received and reviewed the February 2008 final report for Recommendations and Justifications for Modifications for Use Restrictions Established under the U.S. Department of Energy, National Nuclear Security Administration, Nevada Site Office. The NDEP approves the requested changes to the previously agreed upon use restrictions for those Corrective Action Sites (CASs) as described in the report.

Address any questions regarding this matter to either Ted Zaferatos at (702) 486-2850, ext. 234 , or me at (702) 486-2850, ext. 231.

Sincerely

\section{/s/ Tim Murphy}

\section{T.H. Murphy}

Chief

Bureau of Federal Facilities

$\mathrm{TZ}$

cc: $\quad$ E.F. DiSanza, WMP, NNSA/NSO

FFACO Group, PSG, NNSAINSO, Las Vegas, NV

David C. Loewer, DTRAVCXT1, M/S 645, Mercury, NV

W.R. Griffin, SNJV/DTRA, M/S 645, Mercury, NV

T.A. Thiele, NSTec, Las Vegas, NV

R.F. Boehlecke, SNJV, Las Vegas, NV

K. J. Cabble, ERP, NNSANSO, Las Vegas, NV

John Wong. Jeff MacDougall, Dennis Nicodemus, NDEP Las Vegas, NV 


\subsection{CAU 358, Areas 18, 19, 20 Cellars/Mud Pits}

\subsection{CAS Descriptions}

Corrective Action Unit 358 has 17 CASs, eight of which have associated URs. Modifications to URs are proposed for the following seven URs at CAU 358 CASs located in Area 20 of the NTS:

- CAS 20-23-02 - Postshot Cellar

- CAS 20-23-03 - Cellar

- CAS 20-23-04 - Postshot Cellar

- CAS 20-23-05 - Postshot Cellar

- CAS 20-23-06 - Cellar

- CAS 20-37-01 - Cellar \& Mud Pit

- CAS 20-37-05 - Cellar

Corrective Action Site 20-23-02 is an open post-test cellar that is $9 \mathrm{ft}$ deep. The cellar floor contains an unknown amount of soil with small amounts of organic material and possible drilling material. A stand pipe protrudes out the top of the cellar. The walls of the cellar are lined with corrugated steel. The cellar is posted as an "Underground Material" (URMA) (NNSA/NSO, 2003h).

Corrective Action Site 20-23-03 is the U-20az open post-test cellar. The cellar floor contains an unknown amount of dark soil with small amounts of organic material and possible drilling material. The walls of the cellar are lined with corrugated steel. The cellar is approximately $12 \mathrm{ft}$ deep and is posted as "Caution Cellar 20az" (NNSA/NSO, 2003h).

Corrective Action Site 20-23-04 is a post-test cellar that was backfilled with soil/gravel. The approximate depth of the cellar is $14.5 \mathrm{ft}$ with a diameter of $9 \mathrm{ft}$. Protruding from the backfill is a metal posting identifying the cellar as "U-20am Postshot" (NNSA/NSO, 2003h).

Corrective Action Site 20-23-05 is located approximately $450 \mathrm{ft}$ southwest of U-20ab. This CAS is a post-test cellar that is open. The cellar floor contains an unknown amount of soil with small amounts of organic material and possible drilling material, and a standpipe protrudes from the top of the cellar. The walls of the cellar are lined with corrugated steel. The cellar is $10 \mathrm{ft}$ deep and is posted as an "URMA" (NNSA/NSO, 2003h).

Corrective Action Site 20-23-06 is located to the west of U-20ac. This post-test cellar is open and is approximately $9 \mathrm{ft}$ deep. The cellar floor contains an unknown amount of soil with small amounts of organic material and possible drilling material. A stand pipe is located within the 
cellar and the walls are lined with corrugated steel. The cellar is posted as an URMA (NNSA/NSO, 2003h).

Corrective Action Site 20-37-01 is located 350 yards northeast of U-20aa. This CAS consists of a post-test cellar approximately $9 \mathrm{ft}$ deep that is open, and a mud pit (approximately 65 by $30 \mathrm{ft}$ ) containing drilling mud and/or drill cuttings. The cellar floor contains an unknown amount of soil with small amounts of organic material and possible drilling material. The walls of the cellar are lined with a square metal casing. Both the cellar and mud pit are posted as an URMA (NNSA/NSO, 2003h). The cellar was listed as an active UGTA monitoring well.

Corrective Action Site 20-37-05 is an open post-test cellar approximately $12 \mathrm{ft}$ deep, and has a stand pipe protruding out the top of the cellar. The cellar floor contains an unknown amount of soil with small amounts of organic material and possible drilling material. The walls of the cellar are lined with corrugated steel. The cellar is posted as an URMA (NNSA/NSO, 2003h).

\subsection{Current Use Restriction Description}

The future use of any land affected by all URs in this CAU is restricted from any DOE or Air Force activity that may alter or modify the containment control, as approved by the state and identified in the CAU CR or other CAU documentation, unless appropriate concurrence is obtained in advance. As part of closure activities, all CAU 358 CASs were backfilled with clean fill and closed in place with a UR. The UR boundaries are defined by the corner points of existing facility demarcation fences or by the cement pad corners. The UR for CAS 20-37-01 applies to the cellar only. There are no site monitoring requirements (NNSA/NSO, 2004b).

\subsection{Basis for Current Use Restriction}

Soil samples were collected and analyzed for VOCs, SVOCs, total RCRA metals, TPH full scan, PCBs, and gamma spectroscopy. Petroleum hydrocarbons (diesel, gasoline, oil, and TPH) were detected above the PAL of $100 \mathrm{mg} / \mathrm{kg}$ in six samples. Petroleum hydrocarbons were the only COPCs detected above action levels; no VOCs or SVOCs were detected above PALs. (NNSA/NSO, 2003h).

Table 17-1 contains analytical results of all COCs at CAU 358 that are the basis for the current URs. The sample matrix for all samples is soil. 
Table 17-1

Sample Results for COCs at CAU 358 Used To Establish Current Use Restriction

\begin{tabular}{||c|c|c|c||}
\hline \multirow{2}{*}{ Sample ID } & Diesel & Oil & TPH \\
\cline { 2 - 4 } & $\begin{array}{c}\text { PAL } \\
100 \mathbf{~ m g} / \mathbf{k g}\end{array}$ & $\begin{array}{c}\text { PAL } \\
100 \mathbf{~ m g} / \mathbf{k g}\end{array}$ & $\begin{array}{c}\text { PAL } \\
100 \mathbf{~ m g} / \mathbf{k g}\end{array}$ \\
\hline \hline $202302-9-C 1$ & 280 & 2,600 & 2,880 \\
\hline $202303-12-C 1$ & 430 & 4,900 & 5,330 \\
\hline $202305-10-C 1$ & 360 & 2,700 & 3,000 \\
\hline $202306-9-C 1$ & -- & 230 & 248 \\
\hline $203701-9-C 1$ & -- & 250 & 290 \\
\hline $203705-12-C 1$ & -- & 3,700 & $3,735.1$ \\
\hline
\end{tabular}

ID = Identification

$\mathrm{mg} / \mathrm{kg}=$ Milligrams per kilogram

$\mathrm{PAL}=$ Preliminary action level

$\mathrm{TPH}=$ Total petroleum hydrocarbons

$--=$ No detects above action levels

\subsection{Basis for Use Restriction Modification}

The revised FALs associated with the TPH contamination were established based on the PALs of hazardous constituents of TPH diesel as described in Section 2.2.2. Hazardous constituents of TPH diesel were not detected in any of the samples at concentrations greater than their respective PALs (NNSA/NSO, 2003h). Therefore, no contaminants are present at this site in concentrations exceeding the revised FALs, and all revised FALs were established at the PAL concentrations.

\subsection{Proposed Modification}

Remove the FFACO UR and associated fencing and postings from this site. 


\section{References}

FFACO, see Federal Facility Agreement and Consent Order.

Federal Facility Agreement and Consent Order. 1996 (as amended). Agreed to by the State of Nevada; U.S. Department of Energy, Environmental Management; U.S. Department of Defense; and U.S. Department of Energy, Legacy Management.

NNSA/NSO, see U.S. Department of Energy, National Nuclear Security Administration Nevada Site Office.

U.S. Department of Energy, National Nuclear Security Administration Nevada Site Office. 2003h. Streamlined Approach for Environmental Restoration Plan for Corrective Action Unit 358: Areas 18, 19, 20 Cellars/Mud Pits, Nevada Test Site, Nevada, Rev. 1, DOE/NV--837-REV 1. February. Las Vegas, NV.

U.S. Department of Energy, National Nuclear Security Administration Nevada Site Office. 2004b. Closure Report for Corrective Action Unit 358: Areas 18, 19, 20 Cellars/Mud Pits, Nevada Test Site, Nevada, Rev 0, DOE/NV--944. January. Las Vegas, NV.

U.S. Department of Energy, National Nuclear Security Administration Nevada Site Office. 2004f. NV/YMP Radiological Control Manual, DOE/NV--11718-079, Rev. 5. Prepared by Bechtel Nevada. Las Vegas, NV.

U.S. Department of Energy, National Nuclear Security Administration Nevada Site Office. 2006c. Industrial Sites Project Establishment of Final Action Levels, Rev. 0, DOE/NV--1107. Las Vegas, NV. 


\section{Library Distribution List}

\section{$\underline{\text { Copies }}$}

U.S. Department of Energy

National Nuclear Security Administration

Nevada Site Office

Technical Library

P.O. Box 98518, M/S 505

Las Vegas, NV 89193-8518

U.S. Department of Energy

Office of Scientific and Technical Information

P.O. Box 62

Oak Ridge, TN 37831-0062

Southern Nevada Public Reading Facility

c/o Nuclear Testing Archive

P.O. Box 98521, M/S 400

Las Vegas, NV 89193-8521

Manager, Northern Nevada FFACO

Public Reading Facility

c/o Nevada State Library \& Archives

100 N Stewart Street

Carson City, NV 89701-4285
1 (Uncontrolled, electronic copy)

1 (Uncontrolled, electronic copy)

2 (Uncontrolled, electronic copies)

1 (Uncontrolled, electronic copy) 